\title{
KOMPOSISI MIKROPLASTIK PADA ORGAN SARDINELLA LEMURU YANG DIDARATKAN DI PELABUHAN SENDANGBIRU, MALANG
}

\author{
Defri Yona $^{\text {a,d, }}$, Ledhyane Ika Harlyan ${ }^{\text {b,d }}$, M. Arif Zainul Fuad ${ }^{\text {a,d }}$, Yuniar Ponco Prananto ${ }^{c}$, Diana \\ Ningruma $^{\text {, }}$ Mangesti Reza Evitantri ${ }^{\mathrm{a}}$ \\ aProgram Studi Ilmu Kelautan, Fakultas Perikanan dan Ilmu Kelautan, Universitas Brawijaya, Malang \\ ${ }^{b}$ Program Studi Pemanfaatan Sumberdaya Perikanan, Fakultas Perikanan dan Ilmu Kelautan, \\ Universitas Brawijaya, Malang \\ 'Jurusan Kimia, Fakultas Matematika dan Ilmu Pengetahuan Alam, Universitas Brawijaya, Malang \\ ${ }^{\mathrm{d}}$ Marine Resources Exploration and Management Research Group, Fakultas Perikanan dan Ilmu Kelautan, \\ Universitas Brawijaya, Malang \\ J1. Veteran, Kota Malang, Jawa Timur 65145, Indonesia \\ *Koresponden Penulis: defri.yona@ub.ac.id
}

\begin{abstract}
Abstrak
Mikroplastik sebagai hasil degradasi sampah plastik besar telah mencemari lingkungan perairan. Mikroplastik di perairan ini berpotensi untuk terakumulasi dalam tubuh organisme termasuk ikan. Penelitian ini bertujuan untuk menganalisis dan membandingkan mikroplastik pada insang, saluran pencernaan dan daging ikan lemuru (Sardinella lemuru) yang didaratkan di Pelabuhan Sendangbiru, Malang. Pengumpulan sampel ikan dilakukan pada Bulan Maret 2020 dengan membeli 10 ekor ikan hasil tangkapan nelayan dengan kisaran ukuran 11-15 cm. Analisis laboratorium dilakukan mulai dari mengukur panjang $(\mathrm{cm}) \mathrm{dan}$ berat (g) ikan, melakukan pembedahan masing- masing organ, destruksi bahan organik dan identifikasi mikroplastik menggunakan mikroskop. Destruksi bahan organik dilakukan dengan merendam sampel organ yang sebelumnya telah ditimbang berat basahnya menggunakan larutan $\mathrm{H}_{2} \mathrm{O}_{2} \quad 30 \%$ dan $\mathrm{Fe}$ (II) $0.05 \mathrm{M}$. Sampel diinkubasi selama 24 jam hingga sampel beserta bahan organik hancur. Tiga jenis mikroplastik ditemukan di seluruh sampel organ ikan dengan dominansi jenis fiber (54\%), diikuti oleh fragmen (43\%) dan film (3\%). Keberadaan mikroplastik pada ikan dapat dikaitkan dengan keberadaan mikroplastik di perairan. Komposisi jenis mikroplastik berbeda untuk setiap organ. Fragmen ditemukan paling banyak pada insang, sedangkan pada saluran pencernaan dan daging didominasi oleh jenis fiber. Film ditemukan dengan jumlah yang paling sedikit pada ketiga organ. Keberadaan mikroplastik pada insang dan saluran pencernaan berkaitan dengan interaksi langsung ikan dengan lingkungan melalui pernapasan dan proses makan, sedangkan mikroplastik pada daging karena adanya proses translokasi atau perpindahan antar organ.
\end{abstract}

Kata kunci: daging, insang, plastik, saluran pencernaan, sarden

\begin{abstract}
Microplastic as the result of degradation of plastic wastes has become major concern in the marine environment. Once entering the ocean, it can be ingested by various marine organisms including fish. This study aimed to analyze and compare microplastics in the gills, gastrointestinal tracks and muscle of Sardinella lemuru from Sendangbiru, Malang. Ten fish samples were collected from the fishermen on March 2020 with the size of 11-15 cm. Laboratory analysis was conducted from the measurement of the total length $(\mathrm{cm})$ and weight $(\mathrm{g})$ of each sample, dissection of each organ, degradation of organic matter and microplastic identification using microscope. Organic matter degradation was conducted using $\mathrm{H}_{2} \mathrm{O}_{2} 30 \%$ and $\mathrm{Fe}$ (II) 0.05 $\mathrm{M}$ and samples were left overnight for the organic matter to completely degraded. Three types of microplastic were found with the highest was fiber (54\%) followed by fragment $(43 \%)$ and film $(3 \%)$. The presence of microplastics in the fish organs might be related with microplastics in the environment. The composition of microplastics was different in each organ. Fragment was observed the most in the gills, whereas fiber dominated in the gastrointestinal tracks and also fish muscle. Film was found the least in all the three organs. Microplastics in the gills and gastrointestinal tracks were related to the osmoregulatory and feeding process, respectively, while microplastics in the fish muscle might be due to translocation process between the organs.
\end{abstract}

Keywords: Gastrointestinal tracks, gills, muscle, plastic, sardine 


\section{PENDAHULUAN}

Mikroplastik adalah plastik berukuran $<5$ $\mathrm{mm}$ yang sebagian besar berasal dari degradasi dan fragmentasi plastik-plastik berukuran besar akibat proses mekanis dan radiasi sinar matahari [1]-[3]. Keberadaan mikroplastik telah ditemukan di hampir semua wilayah perairan mulai dari wilayah pesisir yang dekat dengan aktivitas manusia sebagai sumber pencemaran plastik [4]-[6] hingga ke wilayah terpencil yang jauh dari aktivitas manusia [7], [8]. Mikroplastik di lingkungan perairan ini berpotensi mengancam kehidupan biota dari trofik level terendah seperti plankton [9], [10] hingga predator seperti ikan [11]-[13], penyu [14], [15] bahkan burung laut [16].

Keberadaan mikroplastik pada berbagai spesies ikan telah banyak diteliti mulai dari ikan yang hidup di habitat estuari, pelagis hingga demersal [13], [17], [18]. Sebagian besar peneliti menganalisis keberadaan mikroplastik hanya pada saluran pencernaan ikan [12], [13], [18]-[20], namun ada juga yang menganalisis mikroplastik pada organ insang, daging dan juga liver [21], [22]. Perbedaan fungsi organ berpotensi mengakumulasi mikroplastik dalam jumlah yang berbeda.

Pelabuhan Sendangbiru atau secara resmi disebut Pelabuhan Perikanan Pantai Pondokdadap telah dibangun sejak 1987 dan dikembangkan menjadi salah satu pusat pertumbuhan ekonomi perikanan di wilayah selatan Propinsi Jawa Timur. Pelabuhan ini menjadi tempat pendaratan ikan skala besar dari berbagai jenis ikan konsumsi yang ditangkap dari laut selatan. Salah satu hasil tangkapan penting yang didaratkan di Pelabuhan Sendangbiru adalah Sardinella lemuru. Lemuru adalah jenis ikan pelagis kecil yang dijadikan produk ikan sarden lokal dan termasuk salah satu ikan yang banyak dikonsumsi oleh masyarakat. Oleh karena itu penelitian ini dilakukan untuk menganalisis serta membandingkan konsentrasi mikroplastik pada insang, saluran pencernaan dan daging ikan S. lemuru yang di daratkan di Pelabuhan Sendangbiru, Kabupaten Malang.

\section{BAHAN DAN METODE}

\section{Sampel ikan}

Pengumpulan sampel ikan dilakukan pada Bulan Maret 2020. Sebanyak 10 ekor S. lemuru didapatkan dari hasil tangkapan nelayan yang didaratkan di Pelabuhan Sendangbiru (Gambar 1). Ikan yang dikumpulkan dipilih yang memiliki ukuran sama dengan kisaran panjang $11-15 \mathrm{~cm}$. Kategori ukuran ini dikenal sebagai jenis ikan lemuru protolan, merupakan ukuran lemuru yang paling banyak ditemukan di perairan selatan Jawa dan Selat Bali. Seluruh sampel ikan dimasukkan ke dalam coolbox untuk dianalisis lebih lanjut di Laboratorium Eksplorasi Sumberdaya Perikanan dan Kelautan, Universitas Brawijaya. 


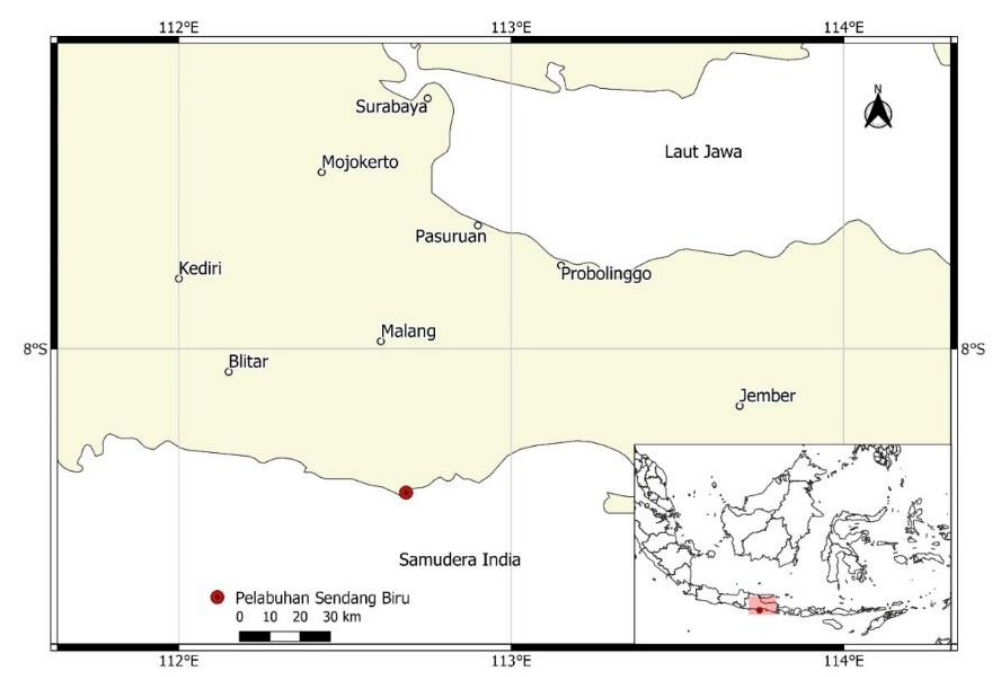

Gambar 1. Peta lokasi Pelabuhan Sendangbiru tempat pengumpulan sampel S. lemuru (Sumber: Peta Natural Earth)

\section{Analisis Mikroplastik}

Sebelum dilakukan pembedahan, sampel ikan diukur panjang $(\mathrm{cm})$ dan beratnya $(\mathrm{g})$. Pembedahan dilakukan untuk memisahkan insang, saluran pencernaan dan daging ikan. Insang dan saluran pencernaan dianalisis secara keseluruhan, sedangkan daging diambil pada tiga titik, yaitu: dekat anus, tengah dan dekat esofagus. Masing-masing organ ditimbang beratnya (g) menggunakan timbangan digital. Untuk memudahkan proses destruksi bahan organik dan lemak yang terdapat pada organ, setiap sampel ditumbuk pelan menggunakan alu dan mortar.

Analisis mikroplastik pada organ ikan dilakukan mengacu pada metode yang dikeluarkan oleh Masura dan Foster [23] yang telah dimodifikasi. Sampel organ yang telah hancur melalui proses penumbukan ditambahkan larutan $\mathrm{H}_{2} \mathrm{O}_{2} 30 \%$ dan $\mathrm{Fe}$ (II) 0.05 M hingga terendam. Sampel ditutup menggunakan alumunium foil dan diinkubasi pada suhu ruang selama 24 jam. Selanjutnya dilakukan pemanasan dan homogenisasi menggunakan hotplate stirrer dengan suhu $75^{\circ} \mathrm{C}$ selama 30 menit. Apabila masih terdapat bahan organik yang belum larut, kembali ditambahkan larutan $\mathrm{H}_{2} \mathrm{O}_{2} 30 \%, \mathrm{Fe}$ (II) $0.05 \mathrm{M}$ dan diinkubasi hingga sampel hancur. Jika sampel sudah hancur dan larutan berubah warna menjadi kuning bening, dilakukan penyaringan menggunakan kertas saring Whatman no. 41.

\section{Identifikasi Mikroplastik}

Proses identifikasi jenis mikroplastik dilakukan menggunakan mikroskop okuler (Olympus MCX100) pada perbesaran 4X/0.10. Sampel pada kertas Whatman dipindahkan di atas cawan petri dan didiamkan hingga kering untuk memudahkan proses identifikasi. Identifikasi dilakukan dengan membedakan mikroplastik ke dalam tiga jenis yaitu fiber, film dan fragmen. Beberapa penelitian telah menjelaskan ciri-ciri setiap jenis mikroplastik untuk memudahkan proses identifikasi secara visual [4], [6], [24]. Fiber dikenali dari bentuknya yang panjang dan menyerupai tali atau benang. Fragmen adalah pecahan plastik berukuran besar yang cenderung berbentuk kotak tidak beraturan dengan ujung-ujung bergerigi. Film hadir dalam bentuk lembaran tipis hasil degradasi plastik kemasan atau tas pembungkus. Mikroplastik yang ditemukan dihitung berdasarkan berat basah organ dengan perhitungan mengacu pada Digka et al. [25]. 


\section{HASIL DAN PEMBAHASAN}

\section{Komposisi mikroplastik}

Sepuluh ekor ikan S. lemuru dengan panjang $17,4 \pm 2,2 \mathrm{~cm}$ dan berat $12,5 \pm 0,5 \mathrm{~g}$ dianalisis kandungan mikroplastiknya pada insang, saluran pencernaan dan daging. Tiga jenis mikroplastik yaitu fiber, film dan fragmen ditemukan di hampir semua sampel dan organ ikan. Secara keseluruhan, fiber mendominasi
(54\%) yang diikuti oleh fragmen $(43 \%)$ dan sangat sedikit jenis film (3\%) (Gambar 2). Komposisi persentase jenis mikroplastik berbeda antar organ ikan (Gambar 3). Fragmen mendominasi pada insang ikan (74 \%), sedangkan fiber mendominasi pada bagian saluran pencernaan $(79 \%)$ dan daging ikan (73\%). Jenis film ditemukan paling banyak pada daging ikan (6\%) dibandingkan insang dan saluran pencernaan.

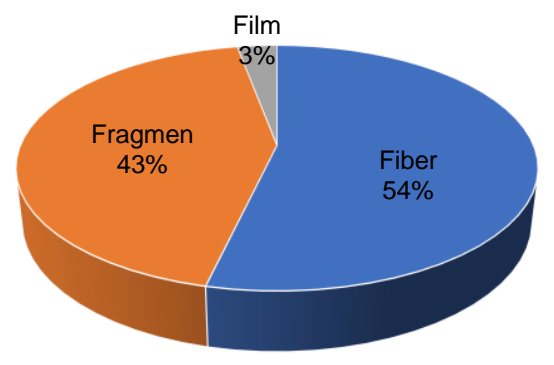

Gambar 2. Persentase kelimpahan total jenis mikroplastik pada seluruh sampel
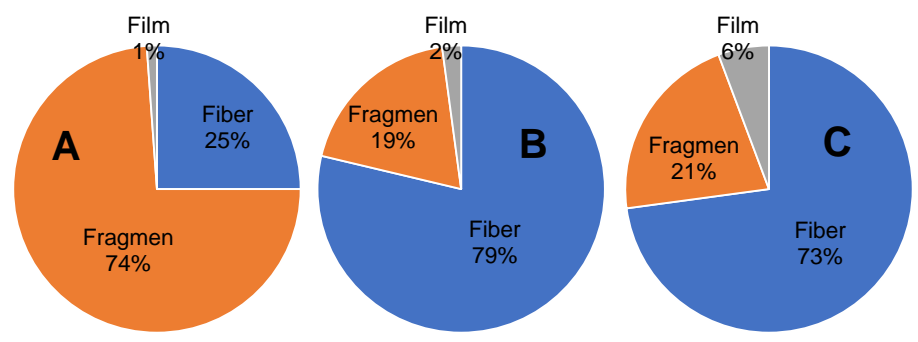

Gambar 3. Persentase kelimpahan total jenis mikroplastik pada masing-masing organ (A) insang, (B) saluran pencernaan dan (C) daging

\section{Kelimpahan jenis mikroplastik}

Total kandungan mikroplastik tertinggi ditemukan pada insang $\left(28,7 \pm 22,6\right.$ item $\left.\mathrm{g}^{-1}\right)$ diikuti pada saluran pencernaan $(6,3 \pm 5,4$ item $\left.\mathrm{g}^{-1}\right)$ dan daging $\left(3,5 \pm 1,9\right.$ item $\left.\mathrm{g}^{-1}\right)$ (Gambar 4). Kelimpahan masing-masing jenis mikroplastik pada setiap organ ikan disajikan pada Gambar 5. Fragmen pada insang ditemukan dengan kelimpahan tertinggi sebesar $21,4 \pm 23,3$ item $\mathrm{g}^{-1}$. Fiber dan film ditemukan dengan kelimpahan yang lebih rendah, masing-masing $7,2 \pm 5,3$ item g ${ }^{-1}$ dan $0,2 \pm 0,6$ item $\mathrm{g}^{-1}$. Berbeda dengan kelimpahan jenis pada insang, saluran pencernaan dan daging $S$. lemuru mengandung jenis fiber yang paling tinggi dibandingkan fragmen dan film. Fiber pada saluran pencernaan adalah $4,9 \pm 3,7$ item $\mathrm{g}^{-1}$ dan pada daging 2,6 $\pm 1,2$ item $\mathrm{g}^{-1}$. Fragmen dan film pada saluran pencernaan ditemukan dengan nilai $1,3 \pm 2,6$ item $\mathrm{g}^{-1}$ dan $0,1 \pm 0,3$ item $\mathrm{g}^{-1}$, berturut-turut. Komposisi kelimpahan mikroplastik pada daging adalah fiber $(2,6 \pm 1,2$ item $\left.\mathrm{g}^{-1}\right)$, fragmen $\left(0,8 \pm 1,0\right.$ item $\left.\mathrm{g}^{-1}\right)$ dan film $\left(0,2 \pm 0,3\right.$ item $\left.\mathrm{g}^{-1}\right)$. 


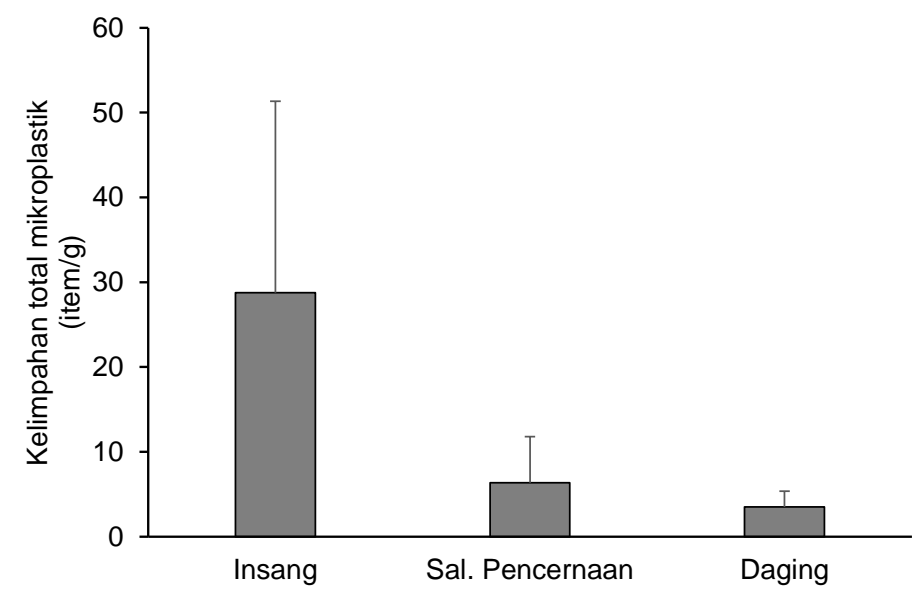

Gambar 4. Kelimpahan total mikroplastik pada masing-masing organ S. lemuru

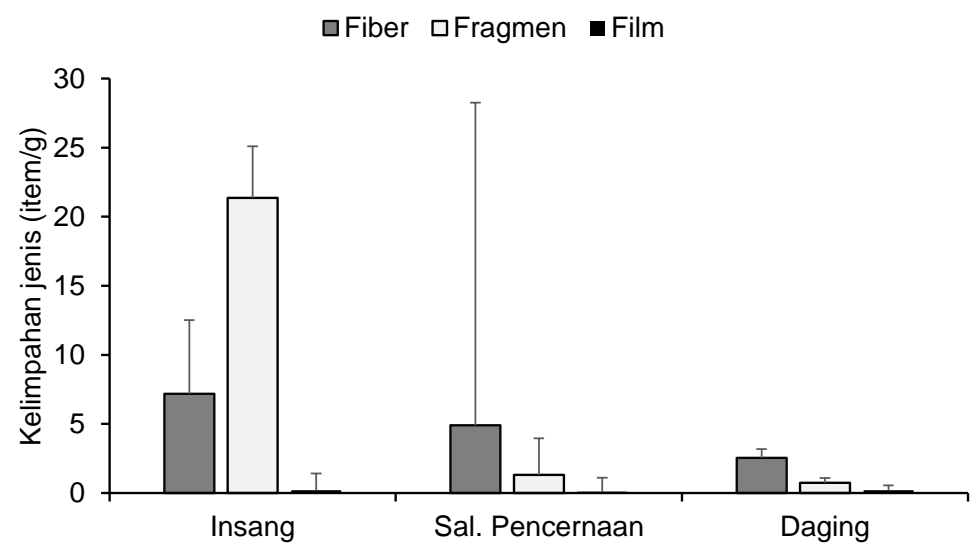

Gambar 5. Kelimpahan jenis mikroplastik pada masing-masing organ S. lemuru

\section{Pembahasan}

Penelitian ini menganalisis komposisi mikroplastik pada insang, saluran pencernaan dan daging ikan S. lemuru. Tidak banyak penelitian yang melihat keberadaan mikroplastik pada ketiga organ tersebut (Tabel 1). Identifikasi mikroplastik yang banyak dipelajari adalah pada saluran pencernaan ikan [26], [27] karena organ ini berkaitan langsung dengan proses makan ikan [28]. Seperti telah banyak disebutkan, masuknya mikroplastik pada biota dari perairan terjadi karena plastik berukuran kecil ini dapat tertelan saat ikan mencari makan [27], [29], [30]. 
Tabel 1. Ringkasan penelitian keberadaan mikroplastik pada organ ikan yang berbeda

\begin{tabular}{|c|c|c|c|c|}
\hline \multirow[t]{2}{*}{ Lokasi Penelitian } & \multicolumn{3}{|c|}{ Jenis organ yang diteliti } & \multirow[t]{2}{*}{ Sumber } \\
\hline & Insang & Saluran pencernaan & Daging & \\
\hline Teluk Persia & $\sqrt{ }$ & $\sqrt{ }$ & $\sqrt{ }$ & [28] \\
\hline Teluk Persia Utara & & - & $\sqrt{ }$ & [31] \\
\hline Malaysia & $\sqrt{ }$ & $\sqrt{ }$ & - & [32] \\
\hline Pantai Timur China & $\sqrt{ }$ & $\sqrt{ }$ & - & [22] \\
\hline Kerala, India & $\sqrt{ }$ & $\sqrt{ }$ & $\sqrt{ }$ & [33] \\
\hline $\begin{array}{l}\text { Teluk Beibu, Laut } \\
\text { China Selatan }\end{array}$ & $\sqrt{ }$ & $\sqrt{ }$ & - & [34] \\
\hline $\begin{array}{l}\text { Zhanjiang, China } \\
\text { Selatan }\end{array}$ & $\sqrt{ }$ & $\sqrt{ }$ & $\sqrt{ }$ & [35] \\
\hline Malang, Indonesia & $\sqrt{ }$ & $\sqrt{ }$ & $\sqrt{ }$ & Penelitian ini \\
\hline
\end{tabular}

Fiber dan fragmen adalah jenis mikroplastik yang banyak terdapat pada organ S. lemuru. Dominansi fiber dan fragmen pada ikan juga telah ditemukan di banyak penelitian [13], [22], [28], [30], [36]. Hal ini karena kedua jenis mikroplastik tersebut adalah jenis yang paling banyak ditemukan di perairan. Keberadaan mikroplastik pada ikan sangat dipengaruhi oleh jenis mikroplastik yang ada di perairan [37], selain juga karena kebiasaan makannya [22]. Hasil penelitian Palermo et al. [38] terhadap 600 ekor S. lemuru yang berasal dari perairan Mindanao Utara, Filipina juga menemukan dominansi fiber $(97,94 \%)$ yang diikuti oleh sedikit fragmen $(1,52 \%)$ dan film $(0,54 \%)$.

Komposisi mikroplastik ditemukan berbeda antar setiap organ. Jenis fragmen mendominasi pada insang, sedangkan fiber ditemukan mendominasi pada saluran pencernaan dan daging S. lemuru. Sampai saat ini belum banyak penelitian yang secara spesifik menjelaskan alasan perbedaan dominansi jenis mikroplastik pada organ ikan yang berbeda. Namun demikian, melalui hasil penelitian ini dapat diduga bahwa dominansi jenis mikroplastik pada organ tertentu berkaitan dengan proses seleksi. Masuknya mikroplastik pada saluran pencernaan ikan berkaitan dengan proses makan ikan dan kemungkinan dominansi fiber terjadi karena bentuk fiber yang dapat menyerupai mangsanya [39]. Sebaliknya, mikroplastik yang masuk melalui insang cenderung bersifat pasif atau tidak sengaja dalam proses pernapasan ikan [22]. Dominansi fiber pada saluran pencernaan dan daging ikan dapat juga dihubungkan dengan karakteristik dari fiber itu sendiri. Fiber memiliki waktu tinggal yang lama di lambung organisme dan juga memiliki aspek ratio yang lebih besar dibandingkan jenis fragmen maupun film sehingga mampu menempel pada jaringan ikan seperti daging [40].

Kelimpahan total mikroplastik tertinggi pada insang dan diikuti oleh saluran pencernaan dan daging S. lemuru. Keberadaan mikroplastik pada organ ikan dari beberapa penelitian cukup bervariasi. Huang et al. [35] mendapatkan mikroplastik lebih tinggi di saluran pencernaan dibandingkan di insang dan tidak menemukan mikroplastik pada daging ikan yang diteliti. Daniel et al. [33] membagi organ ikan yang diteliti menjadi bagian yang tidak bisa dimakan (insang dan saluran pencernaan) dan yang bisa dimakan (daging dan kulit) dan menemukan mikroplastik lebih banyak diperoleh pada bagian yang tidak bisa dimakan. Berbagai faktor diduga dapat mempengaruhi akumulasi mikroplastik pada organ ikan yang berbeda seperti kompleksitas saluran pencernaan yang memungkinkan mikroplastik terjebak dan terakumulasi dalam jumlah banyak [35] maupun kerentanan organ seperti insang yang berinteraksi langsung dengan lingkungan dalam proses pertukaran gas [22]. Selain itu struktur insang yang kompleks juga memungkinkan untuk 
menjebak mikroplastik dalam jumlah yang banyak.

Sampai saat ini keberadaan mikroplastik pada ikan masih diasumsikan berasal dari aktivitas ikan yang berhubungan langsung dengan perairan seperti melalui insang dan saluran pencernaan. Namun mikroplastik juga telah ditemukan pada organ lainnya seperti hati dan daging ([21], [28]. Penelitian pada skala laboratorium menunjukkan bahwa translokasi atau perpindahan mikroplastik terjadi antar organ [21], [26]. Lebih lanjut, Franzellitti et al. [26] menjelaskan bahwa mikroplastik yang ditemukan pada organ yang tidak berhubungan langsung dengan perairan sebagai akibat dari proses translokasi ini berukuran lebih kecil. Meskipun penelitian ini tidak mengukur besarnya mikroplastik, namun rendahnya kandungan mikroplastik pada daging dibandingkan pada insang dan saluran pencernaan dapat digunakan untuk menjelaskan proses translokasi mikroplastik.

\section{KESIMPULAN}

Mikroplastik ditemukan pada ikan $S$. lemuru yang didaratkan di Pelabuhan Sendangbiru, Kabupaten Malang. Secara keseluruhan fiber mendominasi hasil penelitian dibandingkan fragmen dan film, namun pada masing-masing organ terdapat perbedaan dominansi jenis mikroplastik. Fragmen ditemukan lebih tinggi pada insang, sedangkan fiber mendominasi saluran pencernaan dan daging S. lemuru. Perbedaan dominansi jenis antar organ ini diduga disebabkan oleh berbagai faktor seperti karakteristik jenis masing-masing mikroplastik, interaksi jenis mikroplastik di dalam tubuh ikan, struktur organ dan juga proses translokasi. Penelitian lebih lanjut dibutuhkan untuk dapat menjelaskan lebih dalam terkait nasib dan perjalanan (fate and transport) mikroplastik pada ikan.

\section{UCAPAN TERIMA KASIH}

Penelitian ini terlaksana menggunakan dana Hibah Penelitian Unggulan Tahun 2020 Lembaga Penelitian dan Pengabdian kepada Masyarakat Universitas Brawijaya Nomor:
DIPA-042.01.400919/2020. Terimakasih kami sampaikan kepada Danu Setia Wardana dan Dyah Ajeng Pitaloka atas bantuannya dalam analisis mikroplastik di laboratorium.

\section{DAFTAR PUSTAKA}

[1] A. L. Andrady, "Microplastics in the marine environment," Mar. Pollut. Bull., vol. 62, no. 8, pp. 1596-1605, Aug. 2011, doi: 10.1016/j.marpolbul.2011.05.030.

[2] D. K. A. Barnes, F. Galgani, R. C. Thompson, and M. Barlaz, "Accumulation and fragmentation of plastic debris in global environments," Philos. Trans. R. Soc. B Biol. Sci., vol. 364, no. 1526, pp. 1985-1998, Jul. 2009, doi: 10.1098/rstb.2008.0205.

[3] M. Cole, P. Lindeque, C. Halsband, and T. S. Galloway, "Microplastics as contaminants in the marine environment: A review," Mar. Pollut. Bull., vol. 62, no. 12, pp. 2588-2597, Dec. 2011, doi: 10.1016/j.marpolbul.2011.09.025.

[4] Z. Dai et al., "Occurrence of microplastics in the water column and sediment in an inland sea affected by intensive anthropogenic activities," Environ. Pollut., vol. 242, pp. 15571565, Nov. 2018, doi: 10.1016/j.envpol.2018.07.131.

[5] K. I. Jeyasanta, N. Sathish, J. Patterson, and J. K. P. Edward, "Macro-, meso- and microplastic debris in the beaches of Tuticorin district, Southeast coast of India," Mar. Pollut. Bull., vol. 154, p. 111055, May 2020, doi: 10.1016/j.marpolbul.2020.111055.

[6] D. Yona, S. H. J. Sari, F. Iranawati, S. Bachri, and W. C. Ayuningtyas, "Microplastics in the surface sediments from the eastern waters of Java Sea, Indonesia," F1000Research, vol. 8, p. 98, Jan. 2019, doi: 10.12688/f1000research.17103.1.

[7] A. Cincinelli et al., "Microplastic in the surface waters of the Ross Sea (Antarctica): Occurrence, distribution 
and characterization by FTIR," Chemosphere, vol. 175, pp. 391-400, May 2017, doi: 10.1016/j.chemosphere.2017.02.024.

[8] H. K. Imhof et al., "Spatial and temporal variation of macro-, meso- and microplastic abundance on a remote coral island of the Maldives, Indian Ocean," Mar. Pollut. Bull., vol. 116, no. 1-2, pp. 340-347, Mar. 2017, doi: 10.1016/j.marpolbul.2017.01.010.

[9] J. P. G. L. Frias, V. Otero, and P. Sobral, "Evidence of microplastics in samples of zooplankton from Portuguese coastal waters," Mar. Environ. Res., vol. 95, pp. 89-95, Apr. 2014, doi: 10.1016/j.marenvres.2014.01.001.

[10] Mardiyana and A. Kristiningsih, "Dampak pencemaran mikroplastik di ekosistem laut terhadap zooplankton: Review," J. Pengendali. Pencemaran Lingkung., vol. 2, no. 1, p. 8, 2020.

[11] A. L. Lusher, M. McHugh, and R. C. Thompson, "Occurrence of microplastics in the gastrointestinal tract of pelagic and demersal fish from the English Channel," Mar. Pollut. Bull., vol. 67, no. 1-2, pp. 94-99, Feb. 2013, doi: 10.1016/j.marpolbul.2012.11.028.

[12] D. Sarasita, A. Yunanto, and D. Yona, "Kandungan mikroplastik pada empat jenis ikan ekonomis penting di perairan Selat Bali. Jurnal Iktiologi Indonesia," J. Iktiologi Indones., vol. 20, no. 1, pp. 112, 2020, doi: 10.32491/jii.v20i1.508.

[13] M. N. Sathish, I. Jeyasanta, and J. Patterson, "Occurrence of microplastics in epipelagic and mesopelagic fishes from Tuticorin, Southeast coast of India," Sci. Total Environ., vol. 720, 2020, doi: 10.1016/j.scitotenv.2020.137614.

[14] A. G. M. Caron, C. R. Thomas, K. L. E. Berry, C. A. Motti, E. Ariel, and J. E. Brodie, "Validation of an optimised protocol for quantification of microplastics in heterogenous samples: A case study using green turtle chyme,"
MethodsX, vol. 5, pp. 812-823, Jan. 2018, doi: 10.1016/j.mex.2018.07.009.

[15] A. G. M. Caron, C. R. Thomas, K. L. E. Berry, C. A. Motti, E. Ariel, and J. E. Brodie, "Ingestion of microplastic debris by green sea turtles (Chelonia mydas) in the Great Barrier Reef: Validation of a sequential extraction protocol," Mar. Pollut. Bull., vol. 127, pp. 743-751, Feb. 2018, doi: 10.1016/j.marpolbul.2017.12.062.

[16] J. F. Provencher, J. C. Vermaire, S. Avery-Gomm, B. M. Braune, and M. L. Mallory, "Garbage in guano? Microplastic debris found in faecal precursors of seabirds known to ingest plastics," Sci. Total Environ., vol. 644, pp. 1477-1484, 2018, doi: doi.org/10.1016/j.scitotenv.2018.07.101.

[17] F. Bessa et al., "Occurence of microplastics in commercial fish from a natural estuarine environment," Mar. Pollut. Bull., vol. 128, pp. 575-584, 2018.

[18] F. Murphy, M. Russell, C. Ewins, and B. Quinn, "The uptake of macroplastic \& microplastic by demersal \& pelagic fish in the Northeast Atlantic around Scotland," Mar. Pollut. Bull., vol. 122, no. 1-2, pp. 353-359, Sep. 2017, doi: 10.1016/j.marpolbul.2017.06.073.

[19] F. M. Baalkhuyur et al., "Microplastic in the gastrointestinal tract of fishes along the Saudi Arabian Red Sea coast," Mar. Pollut. Bull., vol. 131, pp. 407-415, Jun. 2018, doi: 10.1016/j.marpolbul.2018.04.040.

[20] X. Sun et al., "Characteristics and retention of microplastics in the digestive tracts of fish from the Yellow Sea," Environ. Pollut., vol. 249, pp. 878-885, Jun. 2019, doi: 10.1016/j.envpol.2019.01.110.

[21] C. G. Avio, S. Gorbi, and F. Regoli, "Experimental development of a new protocol for extraction and characterization of microplastics in fish tissues: First observations in commercial 
species from Adriatic Sea," Mar. Environ. Res., vol. 111, pp. 18-26, Oct. 2015, 10.1016/j.marenvres.2015.06.014.

[22] L. Su et al., "The occurrence of microplastic in specific organs in commercially caught fishes from coast and estuary area of east China," $J$. Hazard. Mater., vol. 365, pp. 716-724, Mar. 2019, doi: 10.1016/j.jhazmat.2018.11.024.

[23] B. Masura and A. Foster, "Laboratory Methods for the Analysis of Microplastics in the Marine Environment: Recommendations for quantifying synthetic particles in waters and sediments. NOAA Technical Memoraandum NOS-OR\&R-48,” 2015.

[24] N. H. Mohamed Nor and J. P. Obbard, "Microplastics in Singapore's coastal mangrove ecosystems," Mar. Pollut. Bull., vol. 79, no. 1-2, pp. 278-283, Feb. 2014, doi: 10.1016/j.marpolbul.2013.11.025.

[25] N. Digka, C. Tsangaris, M. Torre, A. Anastasopoulou, and C. Zeri, "Microplastics in mussels and fish from the Northern Ionian Sea," Mar. Pollut. Bull., vol. 135, pp. 30-40, Oct. 2018, doi: 10.1016/j.marpolbul.2018.06.063.

[26] S. Franzellitti, L. Canesi, M. Auguste, R. H. G. R. Wathsala, and E. Fabbri, "Microplastic exposure and effects in aquatic organisms: A physiological perspective," Environ. Toxicol. Pharmacol., vol. 68, pp. 37-51, May 2019, doi: 10.1016/j.etap.2019.03.009.

[27] W. Wang, J. Ge, and X. Yu, "Bioavailability and toxicity of microplastics to fish species: A review," Ecotoxicol. Environ. Saf., vol. 189, p. 109913, Feb. 2020, doi: 10.1016/j.ecoenv.2019.109913.

[28] S. Abbasi, N. Soltani, B. Keshavarzi, F. Moore, A. Turner, and M. Hassanaghaei, "Microplastics in different tissues of fish and prawn from the Musa Estuary,
Persian Gulf," Chemosphere, vol. 205, pp. 80-87, 2018.

[29] A. Lusher, "Microplastics in the Marine Environment: Distribution, Interactions and Effects," in Marine Anthropogenic Litter, M. Bergmann, L. Gutow, and M. Klages, Eds. Cham: Springer International Publishing, 2015, pp. 245307. doi: 10.1007/978-3-319-165103_10.

[30] D. Neves, P. Sobral, J. L. Ferreira, and T. Pereira, "Ingestion of microplastics by commercial fish off the Portuguese coast," Mar. Pollut. Bull., vol. 101, no. 1, pp. 119-126, Dec. 2015, doi: 10.1016/j.marpolbul.2015.11.008.

[31] R. Akhbarizadeh, F. Moore, and B. Keshavarzi, "Investigating a probable relationship between microplastics and potentially toxic elements in fish muscles from northeast of Persian Gulf," Environ. Pollut., vol. 232, pp. 154-163, Jan. 2018, doi: 10.1016/j.envpol.2017.09.028.

[32] S. Karbalaei et al., "Abundance and characteristics of microplastics in commercial marine fish from Malaysia," Mar. Pollut. Bull., vol. 148, pp. 5-15, Nov. 2019, doi: 10.1016/j.marpolbul.2019.07.072.

[33] D. B. Daniel, P. M. Ashraf, and S. N. Thomas, "Microplastics in the edible and inedible tissues of pelagic fishes sold for human consumption in Kerala, India," Environ. Pollut., vol. 266, p. 115365 , Nov. 2020, doi: 10.1016/j.envpol.2020.115365.

[34] J. B. Koongolla et al., "Occurrence of microplastics in gastrointestinal tracts and gills of fish from Beibu Gulf, South China Sea," Environ. Pollut., vol. 258, p. 113734, Mar. 2020, doi: 10.1016/j.envpol.2019.113734.

[35] J.-S. Huang et al., "Microplastic accumulation in fish from Zhanjiang mangrove wetland, South China," Sci. Total Environ., vol. 708, p. 134839, Mar. 2020 , doi: 10.1016/j.scitotenv.2019.134839. 
[36] K. Jabeen et al., "Microplastics and mesoplastics in fish from coastal and fresh waters of China," Environ. Pollut., vol. 221, pp. 141-149, Feb. 2017, doi: 10.1016/j.envpol.2016.11.055.

[37] S. Savoca et al., "Microplastics occurrence in the Tyrrhenian waters and in the gastrointestinal tract of two congener species of seabreams," Environ. Toxicol. Pharmacol., vol. 67, pp. 35-41, Apr. 2019, doi: 10.1016/j.etap.2019.01.011.

[38] J. D. H. Palermo et al., "Susceptibility of Sardinella lemuru to emerging marine microplastic pollution," Glob. J. Environ. Sci. Manag., vol. 6, no. 3, pp.
373-384, Jul. 2020, doi: 10.22034/gjesm.2020.03.07.

[39] H. Nie, J. Wang, K. Xu, Y. Huang, and M. Yan, "Microplastic pollution in water and fish samples around Nanxun Reef in Nansha Islands, South China Sea," Sci. Total Environ., vol. 696, p. 134022, Dec. 2019, doi: 10.1016/j.scitotenv.2019.134022.

[40] R. Qiao et al., "Accumulation of different shapes of microplastics initiates intestinal injury and gut microbiota dysbiosis in the gut of zebrafish," Chemosphere, vol. 236, p. 124334, Dec. 2019 , doi: 10.1016/j.chemosphere.2019.07.065. 